\title{
Supplementation strategies and their effects on ewes colostrum and milk compositions in the initial third lactation period
}

\section{Estratégias de suplementação e seus efeitos sobre a composição do colostro e do leite de ovelhas no terço inicial da lactação}

\author{
Nathália Rafaela Fidelis Campos ${ }^{1}$; Gelson dos Santos Difante ${ }^{2}$; Adriano Henrique \\ do Nascimento Rangel ${ }^{3}$; Stela Antas Urbano ${ }^{3 *}$; João Virgínio Emerenciano Neto ${ }^{4}$; \\ Ana Beatriz Graciano da Costa ${ }^{1}$; Roldão Teixeira de Carvalho Netto ${ }^{1}$; \\ Pedro Henrique Cavalcante Ribeiro ${ }^{1}$; José Igor Gomes Bezerra ${ }^{1}$
}

\begin{abstract}
The objective of this study was to analyze colostrum and milk compositions of ewes kept in pasture receiving different types/levels of supplementation and to analyze milk composition variation throughout the initial third lactation period. After confirmation of pregnancy, 54 ewes were kept in pasture and supplemented from the final third of gestation until weaning with multiple mixture or concentrate $(0.4 \%$ or $0.8 \%$ of body weight). Milk collections were carried out in the postpartum period to collect colostrum (day 0 ), and on the seventh, $14^{\text {th }}, 21^{\text {st }}$ and $28^{\text {th }}$ milking days. Samples were obtained by manual milking and analyzed for protein, fat, casein, lactose, total solids and defatted dry extract. No effects from the different types of supplementation were observed on the colostrum composition or in relation to milk composition. An effect of supplementation was only found for lactose contents, which were higher for animals that consumed a higher level of supplementation. In relation to the milking days, a linear decrease in protein, casein, total solids and defatted dry extract contents was observed between the seventh and the $28^{\text {th }}$ day of lactation. No interaction between type of supplementation and the milking days was observed. The different types of supplementation did not alter the colostrum composition of Santa Inês crossbred ewes, however they had an influence on milk composition. Protein, casein, total solids and defatted dry extract decrease linearly between the seventh and the $28^{\text {th }}$ day of lactation.
\end{abstract}

Key words: Colostrogenesis. Lactation stage. Continuous stocking. Sheep breeding. Lactation peak.

\section{Resumo}

Objetivou-se estudar a composição do colostro e do leite de ovelhas mantidas em pasto recebendo diferentes tipos/níveis de suplemento e analisar a variação da composição do leite ao longo do terço inicial da lactação. Após confirmação de prenhez, 54 matrizes ovinas foram mantidas em pasto e suplementadas do terço final da gestação até o desmame das crias com mistura múltipla ou concentrado

\footnotetext{
1 Discentes, Universidade Federal do Rio Grande do Norte, UFRN, Unidade Acadêmica Especializada em Ciências Agrárias, Distrito de Jundiaí, Macaíba, RN, Brasil.E-mail: nat_rfc@hotmail.com; beatrizcosta.0303@hotmail.com; roldão.agro@hotmail. com; pedrohcrib@hotmail.com; joseigorbezerra@hotmail.com

2 Prof., Universidade Federal do Mato Grosso do Sul, UFMS, Faculdade de Medicina Veterinária e Zootecnia, Campo Grande, MS, Brasil. E-mail: gdifante@hotmail.com

${ }^{3}$ Profs., Universidade Federal do Rio Grande do Norte, UFRN, Unidade Acadêmica Especializada em Ciências Agrárias, Distrito de Jundiaí, Macaíba, RN, Brasil. E-mail: adrianohrangel@yahoo.com.br; stela_antas@yahoo.com.br

${ }^{4}$ Prof., Universidade Federal do Vale do São Francisco, UNIVASF, Petrolina, PE, Brasil. E-mail: joao_neto@zootecnista.com.br

* Author for correspondence
} 
( $0,4 \%$ ou $0,8 \%$ do peso corporal). As coletas de leite ocorreram no pós-parto, para recolhimento do colostro (dia 0 ), e aos sétimo, $14^{\circ}, 21^{\circ}$ e $28^{\circ}$ dias em leite. As amostras foram obtidas por ordenha manual e analisadas em relação aos teores de proteína, gordura, caseína, lactose, sólidos totais e extrato seco desengordurado. Não houve efeito dos diferentes tipos de suplementação sobre a composição do colostro e em relação à composição do leite verificou-se efeito da suplementação apenas sobre os teores de lactose, que foram superiores para os animais que consumiram maior nível de suplementação. Em relação aos dias em leite, verificou-se decréscimo linear nos teores de proteína, caseína, sólidos totais e extrato seco desengordurado do sétimo ao vigésimo oitavo dias de lactação. Não houve interação entre tipo de suplementação e dias em leite. Os diferentes tipos de suplementação não alteram a composição do colostro de ovelhas mestiças de Santa Inês, mas têm influência na composição do leite. A proteína, caseína, sólidos totais e extrato seco desengordurado decrescem linearmente entre o sétimo e vigésimo oitavo dias de lactação.

Palavras-chave: Colostrogênese. Estádio de lactação. Lotação continua. Ovinocultura. Pico de lactação.

\section{Introduction}

Defining food strategies that allow the reduction of the production cycle and the constant supply of young animal carcasses to the market can have beneficial consequences for the sheep meat production chain. It is speculated that improving the meat quality that reaches the final consumer tends to increase the per capita consumption of this product in Brazil (URBANO et al., 2017) and leverage sheep-raising for meat, contributing to consolidating the activity.

When it comes to lamb feeding, colostrum and maternal milk are an indispensable source of nutrients in the first weeks of life. The importance of colostrum lies in the fact that ruminants have the passage of antibodies blocked by their syndesmocorial placenta (FÉRES et al., 2010), making the passive transfer of antibodies - which occurs as a rule by ingestion of colostrum after birth - essential for establishing the newborn's immune system. On the other hand, in addition to being the first food of mammals, milk also supports the high nutritional requirement of ruminant newborns, which present accelerated growth at this stage of life (OWENS et al., 1993). Therefore, breast milk production and composition have high correlations with offspring growth and their performance during the growing period (FERNANDES et al., 2013).

Ewes produce $75 \%$ of the total lactation in the first eight postpartum weeks, and according to Ribeiro et al. (2007), they have a peak in production around the $30^{\text {th }}$ day of lactation, which coincides with the period of greater development in lambs, and thereby justifies the studies focused on the composition and variation of ewes milk during this period. According to Kuchtík et al. (2008), the composition of sheep milk varies according to several factors, however the most expressive are breed, nutrition, animal health, number and lactation stage. Hashemi et al. (2008) reported on the influence of female nutrition on the final third of gestation on the composition of milk secretions, evidencing the existence of few studies aimed at ewe supplementation in the final third of gestation focused on the production and composition of colostrum and milk.

Faced with the influence that colostrum and maternal milk have on the hygiene and growth rate of lambs in their first weeks of life, and considering that this growth may have repercussions on their performance after weaning, our objective was to study the colostrum and ewes milk composition kept in pasture receiving different types/levels of supplement and to analyze the variation of milk composition during the initial third of the lactation period.

\section{Material and Methods}

All procedures were conducted according to the guidelines established by the Brazilian College of Animal Experimentation in the Practice Code for 
Care and Use of Animals for Experimental Purposes and were reviewed and approved by the Ethics Committee on the Use of Animals for Research (CEUA) of the Federal University of Rio Grande do Norte - CEUA/UFRN, under number protocol $053 / 2015$.

The experiment was conducted at the Specialized Academic Unit in Agricultural Sciences (UAECA), Macaíba Campus of the Federal University of Rio Grande do Norte - UFRN (Macaíba-RN), in the
Experimental Area of the Forage Research Group (GEFOR), located at 5'53'34" latitude South and $35^{\circ} 21^{\prime} 50^{\prime}$ ' longitude West.

The climate of the region is characterized as dry sub-humid with water surplus from May to August.

Temperature data were obtained through an INMET database and rainfall control data were collected from a rain gauge installed in the experimental area (Figure 1).

Figure 1. Monthly rainfall precipitation (P) and average temperature (T) throughout the period from January 2015 to June 2016.

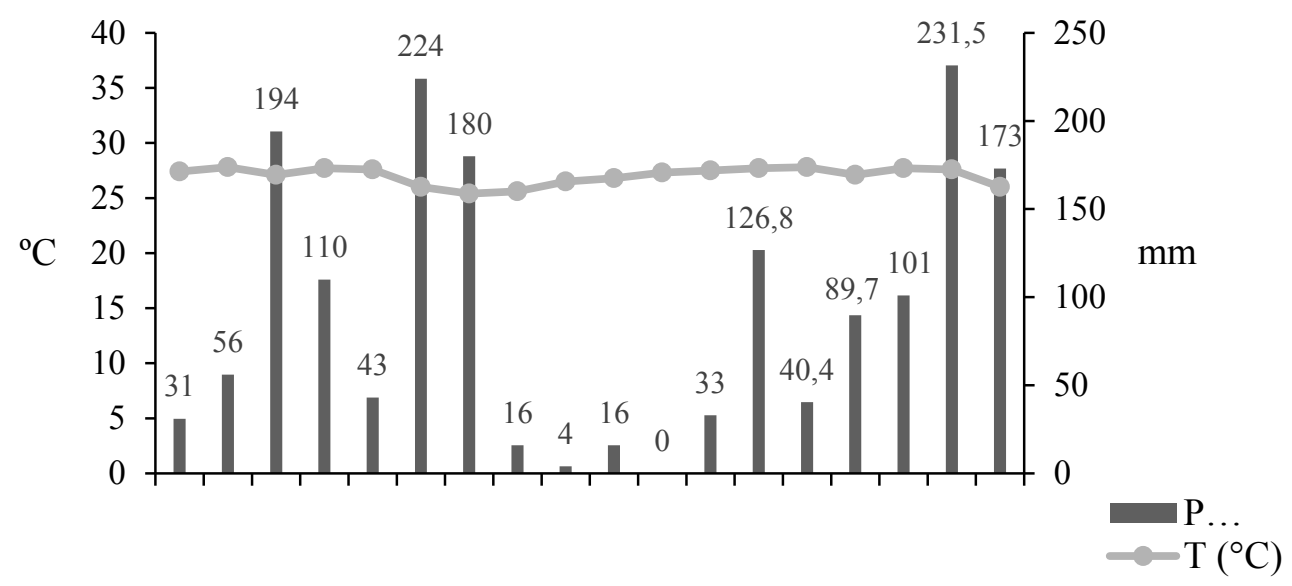

One lot of 62 Santa Inês crossbred ewes was submitted to a 45-day mounting season. After confirmation of pregnancy by ultrasonography examination, 54 ewes were selected and kept in a pasture exclusively composed of Brachiaria brizantha cv. Marandu between 07h00 and 16h00, at which time they were sent to their pens to receive supplementation according to the experimental treatment. A continuous grazing stocking method was employed with variable stocking rate and sampling cycles of the pasture at every 28 days.

The birth season occurred between January 30 and March 20, and 61 lambs were born from single and twin deliveries. During the first seven days of life, lambs and ewes were managed in a maternity pasture formed by Marandu grass. Then, a controlled feeding management was adopted from the $8^{\text {th }}$ day postpartum, in which lambs and mothers remained separated throughout the day and were put together between 5:00 p.m. and 7:00 p.m. The lambs were kept in Massai Panicum maximum cultivar with free access to concentrated supplementation, which was calculated in order to maintain the requirements of lambs in the growth phase with gains of up to 200 $\mathrm{g}$ /day according to NRC recommendations (2007). Definitive weaning occurred at 90 days of age for each lamb.

The ewes were supplemented throughout the period between the final third of gestation and the definite weaning of lambs, with three different supplements being tested: multiple mixture (ad libitum); concentrate supplement offered in an amount equivalent to $0.4 \%$ of body weight (BW); and concentrate supplement offered in an amount 
equivalent to $0.8 \%$ of the BW. Supplements were given daily at $4 \mathrm{pm}$, and the amount was adjusted every 15 days when the ewes were weighed.

Samples of the ingredients of the diets were dried at $55^{\circ} \mathrm{C}$ for $72 \mathrm{~h}$, in a forced air oven, and then grounded using a Wiley Mill with a $1 \mathrm{~mm}$ screen. Dry matter (DM), crude protein (CP) and lignin analyses were performed according to the Association of Official Analytical Chemists (AOAC, 1990), method numbers 934.01 for DM, 981.10 for $\mathrm{CP}$ and 932.01 for lignina. Ether extract (EE) was analyzed by Soxhlet extraction with petroleum ether, method number 920.39 (AOAC, 1990). The concentration of neutral detergent fiber was assayed with a heatstable amylase and corrected for ash based on the procedures described by Mertens (2002), except that the samples were placed in polyethylene pots with $100 \mathrm{~mL}$ of neutral detergent and autoclaved (SENGER et al., 2008). The percentage and bromatological composition of the supplements are described in Table 1.

Table 1. Percentage and chemical composition of the supplementation of ewes between the final third of gestation until weaning.

\begin{tabular}{|c|c|c|c|c|}
\hline & \multicolumn{4}{|c|}{ Ingredients (mixture $\%$ based on the dry matter) } \\
\hline & Ground corn & Soybean meal & $\mathrm{NaCl}$ & Urea \\
\hline Concentrate & 80.5 & 14.6 & 1.2 & 3.7 \\
\hline \multirow[t]{3}{*}{ Multiple mixture } & 40 & 30 & 20 & 10 \\
\hline & \multicolumn{4}{|c|}{ Bromatological composition } \\
\hline & & grass & Multiple mixture & Concentrate \\
\hline Dry matter ${ }^{1}$ & & & 88.51 & 91.32 \\
\hline Mineral matter ${ }^{2}$ & & & 3.38 & 2.15 \\
\hline Ethereal extract ${ }^{2}$ & & & 3.50 & 2.16 \\
\hline Crude protein ${ }^{2}$ & & & 24.84 & 46.46 \\
\hline Neutral detergent fiber ${ }^{2}$ & & & 13.15 & 10.01 \\
\hline Acid detergent fiber ${ }^{2}$ & & & 4.33 & 4.14 \\
\hline Lignin $^{2}$ & & & 1.18 & 0.95 \\
\hline
\end{tabular}

${ }^{1} \mathrm{~g} / 100 \mathrm{~g}$ of natural matter; ${ }^{2} \mathrm{~g} / 100 \mathrm{~g}$ of dry matter.

For evaluation of the morphological components of forage, three composite subsamples were collected and manually separated in the following fractions: leaf blades, stem (stem + sheath) and dead material. After separation, the components were weighed and dried in a forced-air circulation oven at $55^{\circ} \mathrm{C}$ until constant weight. The morphological components were expressed as percentage $(\%)$ of the forage mass. The average forage mass production during the experiment was $6,562.2 \mathrm{~kg}$ of $\mathrm{DM} / \mathrm{ha}$, in which $11.2 \%$ were leaf blades, $26.5 \%$ stem and $63.4 \%$ dead material, with a mean accumulation of $65.7 \mathrm{~kg}$ of DM/ha and negative accumulation rate of
$-10.33 \mathrm{~kg}$ of $\mathrm{DM} / \mathrm{ha} /$ day.

Milk and colostrum sample collections occurred during the postpartum period to collect the colostrum (day 0), and on the seventh, $14^{\text {th }}, 21^{\text {st }}$ and $28^{\text {th }}$ milking days. The samples were obtained by manual milking after hygienically cleaning the udder, and the collected material was packed into 40 $\mathrm{ml}$ plastic containers, which were duly identified, kept at temperatures between 2 and $6^{\circ} \mathrm{C}$, and sent to the Milk Quality Laboratory (LABOLEITE) located at the same academic site of UFRN/Macaíba$\mathrm{RN}$ campus. The samples were then submitted 
to infrared absorption analysis (DairySpec $\mathrm{FT}^{\circledR}$ BentleyInstruments Inc., Chasca MN, USA) in order to determine the levels of protein, fat, lactose, casein, total solids and defatted dry extract.

The experimental design was completely random with three treatments and 18 replicates. The data were tabulated in electronic spreadsheets, and then submitted to analysis of variance according to the model below:

$$
Y_{i j}=\mu+T i+\text { resíduo }_{i j}
$$

Where: $Y_{i j}=$ experimental response measured for $\mathrm{i}$ and repetition $\mathrm{j} ; \mu=$ overall mean; $T_{i}=$ effect of treatment $i$, in which $\mathrm{i}=1,2,3$; resídual $_{i j}=$ random error associated with each observation.

When significance for the F test was detected, means were compared (PROC GLM) by Tukey's test, considering a level of 5\% probability for type I error. To evaluate the variation of milk constituents (fat, lactose, protein, casein, total solids and defatted dry extract) according to the milking days, the data were also submitted to regression analysis (PROC
REG), considering a 5\% probability level for type I error. The interactions between supplementation types and milking days were tested; however, their unfolding was not performed due to the lack of significance by the Fisher test $(\mathrm{P}>0.05)$.

\section{Results and Discussion}

No effects of supplementation types on colostrum composition was observed (Table 2), thus corroborating with Hashemi et al. (2008) who stated that different levels of supplementation, especially energy, tend to have an effect on the amount of colostrum produced, but not on the composition of milk secretion. Fernandes et al. (2013) reported a similar composition for the colostrum of animals from the same genetic group. It is worth pointing out that the chemical composition of colostrum changes rapidly during the postpartum period (PATTINSON; THOMAS, 2004), and because the collections were carried out within a standard time interval for all sheep, this led to an absence of divergence in the colostrum composition of the different groups.

Table 2. Mean and coefficient of variation of colostrum and milk constituents from ewes supplemented with multiple mixture, $0.4 \%$ of body weight of concentrate and $0.8 \%$ of the body weight of concentrate.

\begin{tabular}{|c|c|c|c|c|c|c|c|c|}
\hline \multirow{2}{*}{$\begin{array}{c}\text { Variable } \\
(\%)\end{array}$} & \multicolumn{3}{|c|}{ Colostrum } & \multirow{2}{*}{ CV(\%) } & \multicolumn{3}{|c|}{ Milk } & \multirow{2}{*}{$\mathrm{CV}(\%)$} \\
\hline & M.M. ${ }^{1}$ & $0.4 \%$ & $0.8 \%$ & & M.M. & $0.4 \%$ & $0.8 \%$ & \\
\hline Fat & 10.05 & 10.17 & 9.25 & 32.82 & 3.88 & 3.59 & 4.05 & 38.86 \\
\hline Protein & 13.77 & 11.92 & 13.20 & 24.04 & 4.79 & 4.80 & 4.95 & 13.13 \\
\hline Casein & 10.93 & 9.46 & 10.49 & 24.23 & 3.75 & 3.77 & 3.88 & 13.42 \\
\hline Lactose & 2.89 & 3.13 & 3.49 & 23.23 & $5.29 b$ & $5.42 \mathrm{ab}$ & $5.45 \mathrm{a}$ & 7.02 \\
\hline $\mathrm{TS}^{2}$ & 28.24 & 27.17 & 27.08 & 13.46 & $14.97 \mathrm{ab}$ & $14.87 \mathrm{~b}$ & $15.61 \mathrm{a}$ & 11.19 \\
\hline $\mathrm{DDE}^{3}$ & 18.20 & 16.99 & 17.84 & 16.15 & $11.19 b$ & 11.37ab & $11.57 \mathrm{a}$ & 5.84 \\
\hline
\end{tabular}

a,b,c Numbers followed by different letters on the same line indicate a statistically significant difference between treatments. ${ }^{1} \mathrm{M}$.M. $=$ Multiple mixture $;{ }^{2} \mathrm{TS}=$ total solids $;{ }^{3} \mathrm{DDE}=$ defatted dry extract.

In relation to the milk composition, the effect of supplementation was only verified for the lactose content, which was higher for the animals that consumed a higher level of supplementation. Since lactose composes a greater percentage in ewes milk, and the total solids (TS) and defatted dry extract
(DDE) result from the sum of the constituents, higher percentages of TS and DDE were also verified for the ewe's milk that received supplementation amounts equivalent to $0.8 \%$ of body weight.

Ewe's milk differs from other mammals' milk due to the high levels of protein and especially 
fat; a characteristic that provides high yields in the dairy industry. In this study, fat levels were similar to those reported by Fernandes et al. (2013) for the same genotype (4.05\%); however, it remained below the mean reported in the literature for sheep milk $(5.5-7.0 \%)$. This fact may arise from the peculiar characteristic of small ruminants in accumulating $75 \%$ of the fat in the alveolar portion of the mammary gland, which is only more efficiently extracted with the administration of oxytocin (RIBEIRO et al., 2007), but was not performed in this study, and therefore could explain the lower fat content in the analyzed milk.

Although it is known that in addition to genetics, pre and postpartum nutrition have a direct influence on the quantity and quality of the milk produced by ewes, reports in the literature on the variation of lactose due to diet are scarce. Fredeen (1996) stated that lactose variation is more related to milk production than the sheep's diet. However, it is known that propionate is the major gluconeogenic precursor in ruminants (LIMA et al., 2016), and that according to Kozloski (2011), a higher level of concentrate in the diet increases the propionic acid concentration in the rumen, resulting in greater energy availability in the form of glucose, a precursor of lactose. This particularity of energetic metabolism in ruminants could justify the higher levels of lactose observed in ewe's milk who received higher levels of supplementation. Conversely, Fernandes et al. (2013) found no changes in the lactose content of Santa Inês milk when concentrate was included in their diet in the pre and postpartum period, which shows inconsistency in the results in relation to this milk constituent.

No interaction between supplementation types and lactation days was verified, so therefore only variations in the constituents according to the milking days will be discussed (Table 3).

Table 3. Means and regression equations of the sheep milk constituents at the $7^{\text {th }}, 14^{\text {th }}, 21^{\text {st }}$ and $28^{\text {th }}$ days of lactation.

\begin{tabular}{lcccccccc}
\hline \multirow{2}{*}{ Variable (\%) } & \multicolumn{9}{c}{ Days of milk } & \multicolumn{2}{c}{$\mathbf{P}$} & \multirow{2}{*}{ Regression equation } & ${ }^{5} \mathbf{r}^{2}$ \\
\cline { 2 - 7 } & $\mathbf{7}$ & $\mathbf{1 4}$ & $\mathbf{2 1}$ & $\mathbf{2 8}$ & ${ }^{3} \mathrm{~L}$ & ${ }^{4} \mathbf{Q}$ & & - \\
Fat & 3.96 & 3.65 & 3.66 & 4.03 & 0.8325 & 0.1168 & - & 0.98 \\
Protein & 5.20 & 4.90 & 4.72 & 4.56 & $<0.0001$ & 0.4436 & $\hat{\mathrm{Y}}=-0.03 \mathrm{x}+5.37$ & 0.98 \\
Casein & 4.07 & 3.84 & 3.70 & 3.57 & $<0.0001$ & 0.4992 & $\hat{\mathrm{Y}}=-0.0234 \mathrm{x}+4.205$ & - \\
Lactose & 5.41 & 5.46 & 5.40 & 5.28 & 0.0740 & 0.1303 & - & - \\
${ }^{1} \mathrm{TS}$ & 15.70 & 14.99 & 14.87 & 14.99 & 0.0432 & 0.0921 & $\hat{\mathrm{Y}}=-0.0321 \mathrm{x}+15.7$ & 0.59 \\
${ }^{2} \mathrm{DDE}$ & 11.78 & 11.48 & 11.30 & 10.97 & $<0.0001$ & 0.8528 & $\hat{\mathrm{Y}}=-0.0373 \mathrm{x}+12.035$ & 0.98 \\
\hline
\end{tabular}

${ }^{1} \mathrm{TS}=$ total solids; ${ }^{2} \mathrm{DDE}=$ defatted dry extract; ${ }^{3} \mathrm{~L}=$ linear; ${ }^{4} \mathrm{Q}=$ quadratic $;{ }^{5} \mathrm{r}^{2}=$ coefficient of determination.

The levels of protein, casein, total solids and defatted dry extract linearly decreased between the seventh and $28^{\text {th }}$ days of lactation $(\mathrm{P}<0,05$; Table 3$)$. Ochoa-Cordero et al. (2002) reported that there is a negative correlation of milk production with the amount of protein and total solids, characterizing the dilution effect. Therefore, the results found for these constituents are consistent with ewe's milk ascendency towards the lactation peak, which occurs around the $30^{\text {th }}$ day postpartum.
It is important to note that the high milk protein content during the first seven days of lactation may be correlated with the transition phase from colostrum to mature milk, considering that colostrum has a high amount of protein. In relation to casein, a very similar behavior was observed to that of total protein, and it is also worth pointing out that both presented $13 \%$ lower levels on the $28^{\text {th }}$ day than those observed in the milk collected at 7 days postpartum. The fact that this group of proteins 
makes up most of the total milk protein (PECKA et al., 2012) could explain the similarity in the behavior of these variables. Regarding total solids (TS) and defatted dry extract (DDE), it is known that both result from the sum of dairy constituents; therefore, lower percentages verified for these variables during lactation are due to a reduction in protein and casein levels. The TS content observed in this study was lower than that reported by Ochoa-Cordero et al. (2002) who found values between 16.7 and 19.7\% for this variable, while DDE remained within the range of 10.33 to $12.68 \%$ described by the same authors. This behavior was similar when compared to the results found by Ribeiro et al. (2007) for Santa Inês ewes.

Fat and lactose were the only constituents that did not change with the advancing lactation period. The results found in this study for these constituents $(3.82 \%$ and $5.39 \%$, respectively) differed considerably from the results presented by Blagitz et al. (2013) in analyzing the composition of Santa Inês ewe's milk in the first 30 days of lactation, finding $6.75 \%$ for fat and $4.51 \%$ for lactose. In addition to the accumulation of residual milk in the alveoli, it is possible that the low fat content is also related to the dilution effect, demonstrated by the inverse pattern between volume produced throughout lactation and fat content (FERREIRA et al., 2011). Regarding the results verified for lactose, these are consistent with the thesis by Kuchtík et al. (2008), who stated that the lactose content during lactation is the most constant when compared to the other constituents; thus, confirming its role as an osmotic regulator in milk and compensator for the variation in the other components.

\section{Conclusion}

Supplementation with multiple mixture or concentrate does not alter the composition of the Santa Inês crossbred ewes colostrum maintained in Marandu grass; however, lactose, total solids and defatted dry extract levels in milk are higher when the ewes are supplemented with a concentrate amount equivalent to $0.8 \%$ of body weight.

No variation of lactose and fat contents in the milk produced by Santa Inês crossbred ewes in the initial third of lactation was observed; however, protein, casein, total solids and defatted dry extract linearly decrease between the seventh and $28^{\text {th }}$ postpartum days.

\section{References}

ASSOCIATION OF OFFICIAL ANALYTICAL CHEMISTS - AOAC. Official methods of analysis. $15^{\text {th }}$ ed. Arlington: AOAC International, 1990.

BLAGITZ, M. G.; BATISTA, C. F.; GOMES, V.; SOUZA, F. N. de; DELLA LIBERA, A. M. M. Características físico-químicas e celularidade do leite de ovelhas Santa Inês em diferentes estágios de lactação. Ciência Animal Brasileira, Goiânia, v. 14, n. 4, p. 454-461, 2013. DOI: 10.5216/cab.v14i4.14028

FÉRES, F. C.; LOMBARDI, A. L.; BARBOSA, T. D. S.; MENDES, L. C. N.; PEIRÓ, J. R.; CADIOLI, F. A.; FEITOSA, F. L. F. Avaliação da transferência de imunidade passiva em cordeiros com até 30 dias de idade. Brazilian Journal of Veterinary Research and Animal Science, São Paulo, v. 47, n. 3, p. 231-236, 2010.

FERNANDES, S.; SIQUEIRA, E. R.; DOMINGUES, P. F.; PILAN, G. J. G. Efeitos da nutrição, idade a desmama e mastite sobre a qualidade do colostro e leite de ovelhas. Veterinária e Zootecnia, Botucatu, v. 20, n. 4, p. 615-623, 2013.

FERREIRA, M. I. C.; BORGES, I.; MACEDO JUNIOR, G. L.; RODRIGUEZ, N. M.; PENNA, C. F. A. M.; SOUZA, M. R.; CAVALCANTI, L. F. Produção e composição do leite de ovelhas Santa Inês e mestiças Lacaune e Santa Inês e desenvolvimento de seus cordeiros. Arquivo Brasileiro de Medicina Veterinária e Zootecnia, v. 63, n. 2, p. 530-533, 2011.

FREDEEN, A. H. Considerations in the milk nutritional modification of milk composition. Animal Feed Science Technology, Amsterdam, v. 59, n. 1, p. 185-187, 1996. DOI: 10.1016/0377-8401(95)00899-3

HASHEMI, M.; ZAMIRI, M. J.; SAFDARIAN, M. Effects of nutritional level during late pregnancy on colostral production and blood immunoglobulin levels of Karakul ewes and their lambs. Small Ruminant Research, Amsterdam, v. 75, n. 2, p. 204-209, 2008. DOI: 10.1016/j. smallrumres.2007.11.002 
KOZLOSKI, G. V. Bioquímica dos ruminantes. 3. ed. Santa Maria: Universidade Federal de Santa Maria, 2011. $216 \mathrm{p}$.

KUCHTÍK, J.; SUSTOVA, K.; URBAN, T.; ZAPLETAL, D. Effect of the stage of lactation on milk composition, its properties and the quality of rennet curdling in East Friesian ewes. Czech Journal of Animal Science, Czech Republic, v. 53, n. 2, p. 55-63, 2008.

LIMA, E. H. F.; MENDONÇA, C. L.; PAULA CAJUEIRO, J. F. de; CARVALHO, C. C. D.; SOARES, P. C.; SOUTO, R. J. C.; AFONSO, J. A. B. Efeito da monensina sódica sobre o perfil metabólico de ovelhas antes e após o parto. Ciência Animal Brasileira, Goiânia, v. 17 , n. 1, p. $105-118,2016$. DOI: 10.1590/10896891 v17i128370

MERTENS, D. R. Gravimetric determination of amylasetreated neutral detergent fiber in feeds with refluxing in beakers or crucibles: collaborative study. Journal of AOAC International, Rockville, v. 85, n. 6, p. 1217-1240, 2002.

NATIONAL RESEARCH COUNCIL - NRC. Nutrients requirements of sheep. Washington: 389 National Academies Press, 2007. 362 p.

OCHOA-CORDERO, M. A.; TORRES-HERNÁNDEZ, G.; OCHOAALFARO, A. E.; VEGA ROQUE, L.; MANDEVILLE, P. B. Milk yield and composition of Rambouillet ewes under intensive management. Small Ruminant Research, Amsterdam, v. 43, n. 3, p. 269-274, 2002. DOI: 10.1016/S0921-4488(02)00019-6

OWENS, F. N.; DUBENSKI, P.; HANSON, C. F. Factors that alter the growth and development of ruminants. Journal of Animal Science, Oxford, v. 71, n. 11, p. 31383150, 1993. DOI: $10.2527 / 1993.71113138 x$
PATTINSON, S. E.; THOMAS, E. W. The effect of sire breed on colostrum production of crossbred ewes. Livestock Production Science, Roma, v. 86, n. 1, p. 4753, 2004. DOI: 10.1016/S0301-6226(03)00169-6

PECKA, E.; DOBRZAŃSKI, Z.; ZACHWIEJA, A.; SZULC, T.; CZYŻ, K. Studies of composition and major protein level in milk and colostrum of mares. Animal Science Journal, Tokyo, v. 83, n. 2, p. 162-168, 2012. DOI: 10.1111/j.1740-0929.2011.00930.x

RIBEIRO, L. C.; PÉREZ, J. R. O.; CARVALHO, P. H. A.; SILVA, F. F.; MUNIZ, J. A.; OLIVEIRA JÚNIOR, G. M.; SOUZA, N. V. Produção, composição e rendimento em queijo do leite de ovelhas Santa Inês tratadas com ocitocina. Revista Brasileira de Zootecnia, Viçosa, v. 36 , n. 2 , p. $438-444,2007$. DOI: $10.1590 /$ S151635982007000200022

SENGER, C. C. D.; KOZLOSKI, G. V.; SANCHEZ, L. M. B.; MESQUITA, F. R.; ALVES, T. P.; CASTAGNINO, D. S. Evaluation of autoclave procedures for fibre analysis in forage and concentrate feedstuffs. Animal Feed Science and Technology, Amsterdam, v. 146, n. 1-2, p. 169-174, 2008. DOI: 10.1016/j.anifeedsci.2007.12.008

URBANO, S. A.; FERREIRA, M. A.; RANGEL, A. H. N.; LIMA JÚNIOR, D. M.; ANDRADE, R. D. P. X.; NOVAES, L. P. Lamb feeding strategies during the preweaning period in intensive meat production systems. Tropical and Subtropical Agroecosystems, Yucatan, v. 20, n. 1, p. 49-63, 2017. 